\title{
APILAN LAJIKEKOKEIDEN PERUSTAMISEN TEKNIIKASTA
}

\author{
Pentti Teittinen \\ Satakunnan koeasema, Peipohja
}

Saapunut 1. 4. 1960

Rivikylvöä käytettäessä perustetaan apilakokeet tavallisesti joko siten, että kukin ruutu on välittömästi toisensa vieressä tai siten, että ruutujen väliin jätetään riviväliä leveämpi tyhjä tila. Edellisessä tapauksessa rinnakkain olevien ruutujen äärimmäisten rivien välinen etäisyys on yksi riviväli. Jälkimmäisessä tapauksessa taas käytetään tavallisesti kahden rivivälin levyistä tilaa ruutujen välissä.

Kun ruudut liittyvät välittömästi toisiinsa, ruutujen väli ei vaadi harausta, ellei sitä suoriteta ruudun muissakin riviväleissä. Merkityt ruudut erotetaan toisistaan helposti niin kauan kun rivit säilyvät lähes täysinä. Koska apilan täydellinen talvehtiminen on yleensä harvinaista, on kasvusto varsinkin heikoimmin

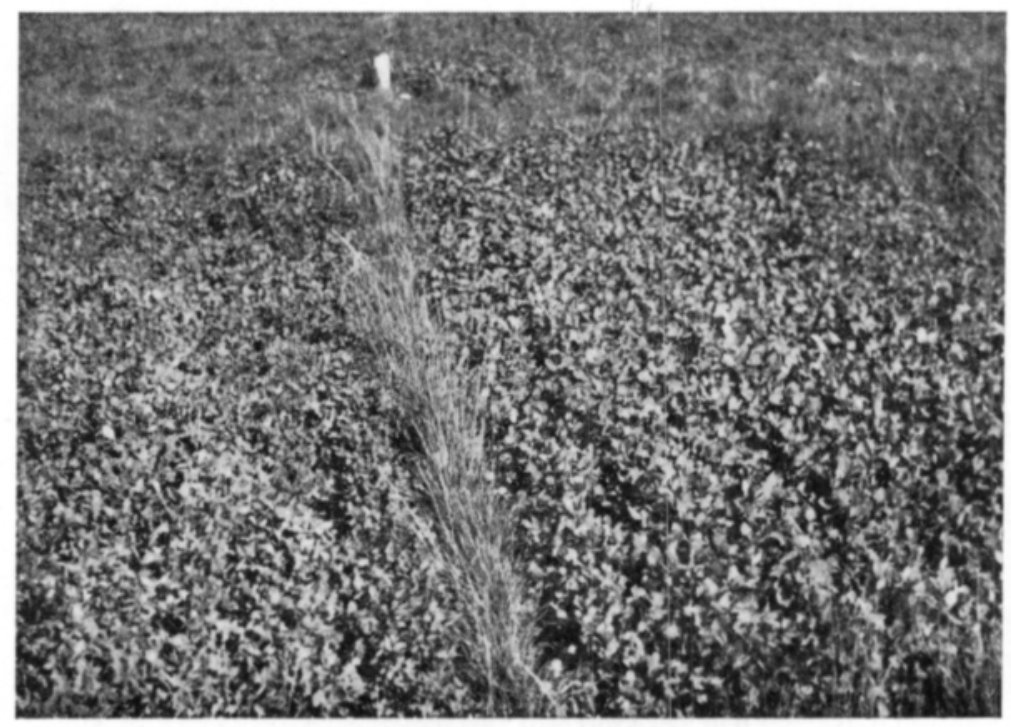

Englantilaisen raiheinän rivi erottaa rehevästi kasvaneet puna-apilaruudut toisistaan. $A$ row of perennial ryegrass separates the plots of red clover. 
talvehtivissa kannıissa usein jo toisen vuoden nurmessa niin aukkoista, että kylvörivien toteaminen on vaikeaa. Ellei rinnakkaisten ruutujen kasvusto poikkea selvästi toisistaan, ruutujen sijainnin toteaminen on työlästä, niiden päissä olevista merkkipaaluista huolimatta. Ruudut olisikin merkittävä jo kylvövuoden syksyllä suojaviljan korjuun jälkeen ja merkkipaalut säilytettävä paikoillaan yli talven, muutoin muodostt:u havaintojen teko aikaisin keväällä (talvehtiminen) ja myöhään syksyllä (tiheys, ‘.pilamätä) aikaa vieväksi.

Tätä haittaa ei ole, jos ruutujen väliin on jätetty riviväliä leveämpi tyhjä tila, jolloin ruudut erottuvat selvästi toisistaan. Kasvuston harvennuttua saattaa kyllä tässäkin tapauksessa esiintyä vaikeuksia ruutujen paikallistamisessa. Lisäksi menetelmä vaatii harauksia ruutujen välin rikkaruohottumisen estämiseksi.

Edellä mainitut haitat voidaan poistaa käyttämällä ruutujen välissä välikasvia. Tällöin ruutujen väliin ei jää tyhjää tilaa ja ne erottuvat kumminkin hyvin toisistaan. Välika:svia riittää yksi rivi kuhunkin ruutujen väliin. Kun riviväli voi olla sama kuin koeruuduissa, koealueen ala lisääntyy esim. $10 \%$ :lla käytettäessä ruudulla kymmentä riviä. Kylvö- ja korjuutyö lisääntyvät samassa suhteessa tai vähemmän, kylvci- ja korjuutavoista riippuen. Sen jälkeen kun ruudut on merkitty kylvöä varten, välirivit voidaan kylvää joko ennen tai jälkeen koeruutujen kylvön. Jos on käytettäyissä useampivantainen kylvökone, johon on asennettavissa syöttösuppilot, voidaan reunimmaiseen vantaaseen syöttävä suppilo täyttää välikasvin siemenellä, jolloin välirivit tulevat kylvetyiksi samalla kuin varsinainen koeruutukin. Korjatessa on suotavinta niittää välirivit sen jälkeen kun kokeen kaikki ruudut on ensin niitetty. Kun koneniitossa niittäjän työtulos muodostuu helposti suuremmakssi kuin haravoitsijoiden ja punnitsijoiden, niittäjä voi käyttää ylimääräisen ajan välirivien niittoon.

Välikasviksi sopii parhaiten pienikasvuinen ja vaatimaton, mutta kestävä heinäkasvi. Kasvinviljelylaitoksella Tikkurilassa on tarkoitukseen käytetty englantilaisen raiheinän Hunsballe-kantaa. Valinge-kanta olisi matalakasvuisempi ja kestävämpi, mutta Hunsballenkin kestävyys on ollut riittävä ainakin 3-vuotisissa nurmissa. Raiheinä säilyy puna-apilan varjostaessa voimakkaastikin ja on siitä syystä välikasviksi erityisen sopiva. Puna-apilalta saamansa typen vaikutuksesta raiheinä joskus saattaa kasvaa tarpeettoman reheväksi.

Koska englantilainen raiheinä on verraten arka pintavesivaurioille, voidaan sitä jossain mää:in käyttää näiden tuhojen indikaattorina. Tuhoutuneesta apilakasvustosta on usein vaikea päätellä mistä vauriot johtuvat. Jos apila on kuollut koeruuduilla, mıtta raiheinä säilynyt väliriveissä, on apilan tuhon syynä luultavimmin apilamätä; missään tapauksessa syynä ei silloin ole ollut pintavesi tai -jää.

Välirivin kasvuston tulee olla tasainen, mutta ei liian tiheä. Rivimetriä koh-

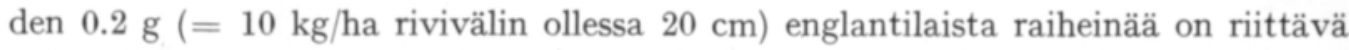
kylvömäärä.

Hyvin talvehtineesta Tammiston puna-apilasta on Kasvinviljelylaitoksella punnittu sato riveittäin kolmelta ruudulta. Satotulokset seuraavassa asetelmassa osoittavat, että englantilainen raiheinä ei ole haitannut apilan reunarivien kasvua. 
Sato $\mathbf{k g}$ tuoreena

\begin{tabular}{rrrrrr} 
Rivi & Ruutu 485 & $\begin{array}{c}\text { Ruutu 523 } \\
\text { (odelma) }\end{array}$ & Ruutu 292 & Keskim. & $\begin{array}{r}\text { Suht. } \\
\text { sato }\end{array}$ \\
& 1956 & 1956 & 1958 & & \\
Raih. & 2.1 & 2.0 & 2.5 & & \\
1 & 2.2 & 2.7 & 3.0 & 2.63 & 100.2 \\
2 & 2.0 & 2.7 & 3.1 & 2.60 & 99.1 \\
3 & 2.3 & 2.5 & 2.7 & 2.50 & 95.3 \\
4 & 2.0 & 3.2 & 2.6 & 2.60 & 99.1 \\
5 & 2.1 & 2.8 & 3.1 & 2.67 & 101.8 \\
6 & 2.4 & 2.5 & 3.1 & 2.67 & 101.8 \\
7 & 2.4 & 2.1 & 3.7 & 2.73 & 104.0 \\
8 & 2.5 & 2.2 & 3.3 & 2.67 & 101.8 \\
9 & 2.1 & 2.7 & 3.0 & 2.60 & 99.1 \\
10 & 2.1 & 3.0 & 2.6 & 2.57 & 97.9 \\
Raih. & 2.4 & 1.8 & 2.7 & & \\
\hline & & & & 2.62 & 100.0
\end{tabular}

Yhteenveto

Kasvinviljelylaitoksella Tikkurilassa on vuodesta 1954 lähtien apilan kantakokeet perustettu siten, että ruutujen väliin on kylvetty rivi englantilaista raiheinää $(10 \mathrm{~kg} / \mathrm{ha}$ rivivälin ollessa $20 \mathrm{~cm})$. Raiheinärivi on helpottanut ruutujen paikallistamista havaintoja suoritettaessa ja satoa korjattaessa. Se on myös jossain määrin auttanut apilan talvehtimisvaurioiden määrittämisessä.

\section{S U M M A R Y :}

THE TECHNIQUE OF ESTABLISHING FIELD EXPERIMENTS WITH CLOVER

Pentri Teittinen

Satakunta Agricultural Experiment Station, Peipohja

Perennial ryegrass (Lolium perenvie) has already been used for several years between the test plots when establishing clover variety experiments at the Department of Plant Husbandry at Tikkurila. A row of ryegrass separates the plots well from each other and facilitates observations. As successful winter survival under Finnish conditions may depend on a number of different factors (low temperature parasitic fungi, damage caused by water and ice), the ryegrass helps in making further ascertainments of the causes of clover destruction. The seed rate of the ryegrass used is $10 \mathrm{~kg} / \mathrm{ha}$. 